\title{
THE ENCROACHMENT OF THE SAHARA ON THE SUDAN
}

IMPRESSED on the parched surface of the Sahara is the skeleton of an ancient river system; regions which are now uninhabitable bear signs of the former existence of a sedentary population; besides abundant fossil remains of aquatic beasts the presence of a strangely varied fauna native to less arid regions has been reported in the very heart of the Sahara. Indeed, there exists abundant evidence that this vast area, now sparsely peopled by a few tribes of predatory nomads and such few agriculturalists as have tenaciously clung to the ever shrinking oases, was once capable of supporting a comparatively large sedentary population. ${ }^{1}$ The change took place before the dawn of history. Our earliest records of the southern fringes of the Sahara, the region with which we are now chiefly concerned, date back to a period not earlier than the seventh century A.D., when the distribution of desert and oases barren plains and fertile forest lands, was much as we find it to-day. M. Duveyrier's contention that "depuis les temps historiques un changement climatérique complet a eu lieu dans toute l'étendue du Sahara, au moins sous le rapport de la quantité des pluies," cannot now claim many supporters. It is equally hard to accept $M$. Gautier's suggestion that in historic times the Niger flowed northward from Timbuktu and emptied itself into the depression known as the Juf, though this may well have been so at an earlier period. That modification has taken place in certain regions of the Sahara and Sudan during historic times is generally agreed, but the nature and extent of these more recent changes still remain matters of doubt. Nor can any definite conclusions be expected till thorough scientific exploration has provided the necessary material for careful research.

Scattered through the abundant literature of these regions 
there occurs much fragmentary evidence relative to desiccation. In the present paper an endeavour has been made to show that from a consideration of the more important evidence it would seem that in certain areas the Sahara is encroaching on the Sudan and, furthermore, that whatever may be the other causes at work, man himself is to no small extent responsible for the desiccation of oases and the fertile plains which lie beyond the actual confines of the desert. In the face of evidence which is sometimes contradictory and of ten of doubiful value no pretence is made to arrive at definite conclusions.

The greater part of the Sahara having reached the extreme limit of desiccation, it is rather to its outer fringes, where desert conditions give way to steppe and open bush, that we look for evidence of progressive desiccation. In a consideration of the process by which oases revert to desert will be found a lesson and a warning, for the same influences which combine to reduce the cultivable areas within the desert appear also to be causing the encroachment of the Sahara on the fertile plains of the Sudan and other fringing areas. It may be well, therefore, to consider first certain evidence of desiccation in the desert itself.

The Romans had not been long in occupation of the North African littoral before they realised that the desert is a relentless foe against which man must wage unremitting war. In the tropical rain-belt of Central Africa the forest is ever ready to reclaim as its own any uncultivated farm; similarly in the Sahara the desert will surely creep in and swallow up an oasis that has been abandoned by man. This is the great law of the Sahara and is in accordance with the theory of Rickmers, who assumed the inherent tendency of deserts to expand. In Tripoli and Fezzan extensive ruins indicate a degree of prosperity which has long since departed. As the Empire waned Tripolitania declined. The desert crept in, bringing with it predatory tribes of nomads. To its departed glory there is no more eloquent testimony than an ancient Roman gateway at Gherria, in the hinterland of Tripoli, which bears the inscription PRO. AFR. ILL. (Provincia Africa Illustris). In Fezzan we find a similar state of affairs. Besides the remnants of 
Roman civilisation there are extensive ruins which date from a far more recent period. There is abundant evidence that the prosperity of Fezzan has been but recently lost, so recently, indeed, that the desert cannot be said to have won the day. Some hope is entertained of re-establishing its former large and prosperous sedentary population. The recent decline is due in large measure to the Turks, who, by their devastating conquest, did much to reduce the cultivated areas. Excessive taxation further served to drive many of the survivors to seek a livelihood elsewhere. The prosperous mercantile community was reduced to penury by the Europea occupation of more southern regions, which effectively put a stop to the slave trade. The ravages of Rabeh in Bornu at the beginning of the present century finally extinguished the trans-Saharan trade and thereby completed the ruin of the Fezzan merchants and the struggling communities of the aases. A recent traveller, Major Hanns Vischer," has compared the present state of the country with the description given by Barth ${ }^{6}$ in the middle of last century. The advance of sand and the shrinkage of oases is everywhere noticeable.

The unfortunate and somewhat precipitate retirement of the Italians from Fezzan on their entry into the Great War threw the country open to hordes of desert tribes who live largely by brigandage and loot. Equally lacking in all sense of honour and courage, they prey upon the broken, spiritless, agricultural communities of the oases. When disappointed of their booty they resort to wanton destruction of wells, palm groves, and carefully irrigated gardens. The reduction of the cultivable areas has been enormously increased by these nomads. The wholesale destruction of the wells and palm groves, on which their very existence depends, has so reduced the settled population that they are unable to offer resistance to the marauding bands. Moreover, they refuse to sink new wells or sow a grain more corn than will suffice their barest needs lest the hard-earned fruits of their labour be seized from them by the hordes of brigands who are ever hovering beyond the horizon. Major Hanns Vischer found that "it is man himself who invites the desert to take possession of the once fertile lands. In the Sahara that man is an Arab or a Tuarek." 
And he might have added a Tubbu. If the advance of the desert in Fezzan is to be arrested a strong central authority must be established capable of reducing the nomads to submission, and thereby guaranteeing the security of the agriculturalists. Once this has been achieved much of the lost area may be brought back into cultivation and the oases saved from the ever encroaching sand.

Of the Libyan oases during last century M. Schirmer has written " la domination des nomades a été funeste aux oasis ... A Farafrah, les habitants ne cultivent plus que la portion des terres située au pied même de leurs murailles, car les jardins éloignés sont la proie des Arabes du Barka et des Bedouins du Nil."•

In the heart of the Sahara lies the rugged and turbulent region of Haggar or Ahaggar. A mission " despatched in Iga4 by the French Government to supplement the work of previous expeditions found in this region abundant evidence of ever increasing aridity and a general decline towards the extreme limit of utter and hopeless desiccation. Besides archæological discoveries indicating the former existence of a higher culture in bygone centuries, much evidence was found of the rapid growth of decay and desolation in quite recent years. In many parts of this region water lies close to the surface, and in certain years actually flows above ground. Wells were found which had but lately fallen into disuse, and there still remained gardens formerly irrigated by surface water from which recent cultivators had been driven by ever increasing aridity. The natives themselves recalled times of comparative prosperity when the tribes were at peace with each other, and wells were more numerous. At the time of their visit the mission found that a section of the Imrads of the Azgueurs were living entirely by pillage at the expense of their neighbours. Where a few cultivators chanced to survive it was found that they grew the minimum of corn necessary to their needs. The Imrads of the Tassili expressed great willingness to return to an agricultural life, provided their crops could be secured against pillage by their predatory neighbours.

The mission reported that at Tarat they found all the conditions necessary for the support of a large sedentary popula-

12 Vol, 20 
tion except security against the descents of nomads. The greater part of this region, however, was found to have passed beyond all possibility of redemption. In conclusion Captain Touchard laid emphasis on the necessity for the French to become the unidisputed masters of the Tassili of the Azgueurs, who are the principal cause of the reduction of the cultivable areas and encroachment of the desert. 'The Azgueurs have more recently been brought to subjection and an increase in the agricultural community has since been reported.

It is interesting to note the strangely varied fauna dis. covered in Haggar. Most of the perennial pools contain fish, and crocodiles survive in more than one district; the presence of antelopes, gazelles, hares, wild cats and moufflon has also been reported. To the south of Temassinin forests of tamarind and ethels barely survive under increasingly adverse conditions. A noted landmark used to be an enormous tamarind tree at Azet in Bangou, which has since fallen a victim to the desert and is now dead.

Fezzan and Haggar are not the only regions of the Sahara which are becoming increasingly arid. There are numerous other districts and oases, the cultivable areas of which are fast shrinking before the encroaching desert. Especially noteworthy is the recently explored Tibesti-Borku region, where Colonel Tilho ${ }^{8}$ has discovered the beds of lakes which have recently dried up. At Tungur, on the Bahr-el-Ghazal, he found abundant evidence of desiccation. South-west of Haggar there lie the ruins of the old town of Es-Suk (the Market), dating back to the fifteenth century but now halfburied beneath the desert sands. ${ }^{10} \mathrm{M}$. Gautier has shown that the part of the Sahara which lies between the Juf and Algeria was fertile in historic times." The western frontier of Egypt and the aases of Kufra ${ }^{19}$ are said to be suffering from increasing aridity. In the oasis of Insalah, an important military post, the encraachment of the desert is causing anxiety." These examples might be many times multiplied, but as in all of them we find conditions similar to those already described, we may now turn to the more important matter of the encroachment of the Sahara on the Sudan. 
To the student of desiccation Senegal is a peculiarly attrac. tive region. Interest is chiefly centred in its well-defined river system, which is fast falling a victim to climatic change. M. Henry Hubert, ${ }^{14}$ as a result of careful investigation, has brought together some interesting evidence of progressive desiccation in this region. Nearly all the valleys of the numerous rivers which drain the country between the Senegal and Gambia rivers are now dry, and desert conditions are becoming increasingly prevalent. The river Bounoun has dried up within the memory of living natives, whose evidence is substantiated by the account of an early European explorer. The Soloum is dry throughout its course except in its estuary, where the water is more saline than that of the ocean owing to evaporation. In those rivers which are still running there is a marked increase in the salinity of their waters. The early explorers reported fresh water at points where the river water to-day is decidedly salt. Although the total discharge of rivers may not have diminished appreciably, there are indications that their flow is becoming more torrential, which would tend to produce increased aridity in the hinterland. Observation shows that the dry river beds are filling with sand and æolian deposits. Wells sunk by Europeans, as well as those of natives, are drying up. According to native tradition, which is substantiated by the accounts of early European explorers, the country used to be more wooded than it is to-day. This need not necessarily be due to climatic change. The relationship between desiccation and deforestation is a matter to which we will revert later. Of great significance is the fact that shrinking wells and failure of crops is causing the sedentary population of Senegal to migrate southwards to less arid regions. As desert-like conditions become more prevalent the country is gradually invaded by pastoral Moors from the north. Nor is this the only part of the Sudan where nomads from the north are replacing agriculturalists who have been driven southwards in search of more humid conditions.

With regard to failure of crops, M. Emile Roubaud, ${ }^{15}$ who was called in to enquire into the decline in the export of ground nuts, the most valuable product of Senegal, found that there has been a continuous fall in the yield of this crop, parallel 
with the decline of the rainfall. Although the rainfall records of this region are so limited that little reliance can be placed on their indications $M$. Roubaud has definitely established the fact that lack of moisture is the real cause of the decreasing yield in ground nuts.

Much of the evidence of desiccation collected by $\mathrm{M}$. $\mathrm{H}$. Hubert in Senegal is consistent with the pulsatory theory of Professor Ellsworth Huntington. A study of the geological deposits of the region has shown that a humid period preceded the present, but that yet again before that there was a period of even greater aridity than we find to-day. The fact that in parts of this region the sand dunes have been fixed by the growth of vegetation has been advanced by some as a proof that more humid conditions are returning. M. Hubert, on the contrary, maintains that Senegal is now entering a period of increased aridity characterised by mobile dunes. A marked tendency in this direction has been observed in the dunes in the neighbourhoods of Dakar and Baol. M. Hubert maintains that the fixing of dunes by vegetation is due to regular periodic rainfall and is only temporary.

Along the Middle Niger a certain amount of fragmentary evidence of desiccation has been collected. Timbuktu affords interesting examples of the effect of zolian deposits. The streets have been raised by sand drifting from the desert to a level much above that of the ancient mosques. During his researches in this region $M$. de Gironcourt investigated an ancient cemetery of the Askias outside Timbuktu which had been completely covered with sand for a hundred years. Further south at Dia, a very ancient town of the fertile province of Massina, the same investigator brought to light an interesting series of carvings (or drawings) which bear witness to the growth of arid conditions in this area. They represent the district at a time when luxuriant vegetation still grew on the Niger banks in parts which are to-day almost bare. It has been suggested that the formation of Lake Faguibine and the adjoining lakes may be due to desiccation. ${ }^{10}$ Lake Faguibine itself is said to be rapidly shrinking. To the east of Timbuktu ruined towns become numerous. The ancient town of Tirekka, of great importance in the time of El Bekri, 
after having fallen a victim to the surrounding desert, has recently been re-discovered ${ }^{17}$ of special interest are extensive ruins in the neighbourhood of Gao ;s further north, in Kidal, more ancient sites are awaiting investigation. The presence of so many ruined sites of ancient towns on this part of the river is not necessarily due to the process of desiccation. This region of the Middle Niger has seen the rise and fall of empires. In its eventful history pillage and destruction constantly recur, and it is small wonder that long periods of turbulence have left an indelible mark on the country. M. Chudeau blames the pastoral Tuarek for the desolation of this once prosperous region.19 There is evidence that the encroachment of the desert on the region lying to the south of the Bend of the Niger has progressed during recent decades. It has been suggested that the desiccation of these parts may have been partly caused by river capture in the Upper Volta region.

Passing eastwards into British territory we come to the Northern Provinces of Nigeria, a region of especial interest on account of its abundant resources and the many unsolved problems presented by the strange complexity and varied cultures of its inhabitants. In the closing years of last century, when the northern Anglo-French frontier was first determined, it was not realised how far south desert conditions prevailed. Subsequently, in 1906, the frontier was moved further south to its present position so as to give the French a strip of fertile territory which could afford them easy access to their Lake Chad territory. To-day this frontier may be taken as a rough indication of where the thinly populated pastures and unsettled conditions which characterise the fringes of the Sahara merge into fertile plains supporting an extensive agricultural community. Along this frontier water supply is the limiting factor in the lives of the people. If the desert wastes of the Sahara are encroaching on the fertile plains of the Western Sudan it is naturally on this frontier that we may expect to find dry river beds, shrinking wells, failing crops, and a southward movement among the agriculturalists, all symptoms of desiccation such as we have already noted on the same parallel of latitude in Senegal. This, in tact, is what we do find, but more especially in Sokoto Province, which 
extends further north than the other frontier provinces, and is consequently an area in which the effects of increasing aridity are more keenly felt by the natives and less likely to escape the notice of administrative officers.

In 1918 Mr. E. J. Arnett, for some time Resident of Solsoto, wrote of this Province: "It is impossible, in my opinion, to question the reality of the desiccation problem that faces us. Whether we consider merely what we have seen from year to year with our own eyes or examine what has been happening during past decades or past centuries, there are the same processes in action."

As the rainfall records of Sokoto only date back to I904, any inference drawn from them must be regarded with due suspicion. The average annual rainfall since our occupation in 1902 up to 1918 was 24.87 ins., showing a fairly irregular decline, reaching a minimum of 16.38 ins. in 1913 , which resulted in a famine in the following year. The province is regarded as a region of declining rainfall, but it has enjoyed particularly heavy rains during the present year (1920), the total fall for which is awaited with interest. Characteristic of Sokoto are numerous lakes of various sizes which are scattered over the province. During recent years the shrinkage in many of these has become increasingly marked. In this connection we have an interesting note by Mr. H. S. W. Edwardes, of the Political Department: "In the Sokoto Province of Nigeria I found lake formation associated with desiccation in the following manner. Tributaries of the Sokoto river which have ceased to flow have their mouths closed by detritus brought down by the flood of the river, which, in raising its own bed, has barred their valleys. The resulting lake was fed each year by the flood water from the river, and the sediment dropped when the water lost its velocity in the backwater round the bar. . . . Lake Kubiri was perfectly dry owing to the failure of the Sokoto river for many years to reach the level of the bar it had constructed when its water supply was more abundant."' Mr. Edwardes goes on to describe how, by cutting a short canal from up-stream, he was able to restore to Lake Kubiri twelve million cubic feet of water. For the direct benefits to the natives derived therefrom at a com- 
THE ENCROACHMENT OF THE SAHARA ON THE SUDAN 183

paratively infinitesimal cost the present writer is able to vouch. Mr. Edwardes has suggested that the formation of Lake Faguibine and its adjoining lakes in the region of Timbuktu may be due to similar causes.

The shrinkage of wells in the northern district of Sokoto has been very marked of recent years and is likely to have farreaching results. In the drier parts of Godabawa the natives sometimes have to travel with their donkeys as much as twenty miles, there and back, for their daily supply of water. At Sokoto itself the water-level appears to be falling with alarming rapidity, and in 1917 the Resident reported that unless artesian water could be found it was not unlikely that within five years it would be necessary to abandon the government station. In 1826 Clapperton wrote in his diary : "They have not been able to make the date tree grow at Soccatoo; whenever it gets a little above ground it rots and dies." 22 Although the modern date-palms in the neighbourhood of the town do not bear fruit they attain considerable size. The inference is that the date palm has benefited by increasing aridity during the past hundred years.

Of very great significance is the restlessness of the natives. The population, which is mainly agricultural, is very unevenly distributed. In the south there are well-watered areas which are only sparsely inhabited. But in the more arid north, owing to immigration from French territory, every square yard of cultivable land is occupied. As a result of the increasing desiccation of the northern part of the province, as well as beyond the frontier, there is a constant movement from the north to the more spacious areas in the south. Nor is this movement of recent origin. If we examine the historical records of the country we find that there has been in the past a constant migration of tribes southwards, notably the Gobirawa, a Hausa speaking people who have played an important part in the history of Sokoto, and who came originally from Agades, far north in the Sahara. According to their traditions the country of Air enjoyed greater fertility in those days.

Since the British occupation of Sokoto in 1902 the Tuarek (Asbenawa) have begun to encroach on our territory. They 
come annually during the dry season in search of pastures for their flocks and herds, returning to their own country at the commencement of the rains. Year by year this seasonal migration has been extended further southward. The endeavours of both the French and British to curb these movements to and fro across the frontier have not met with much success. From the writings of Clapperton and Barth it is evident that before the coming of the French and British the Tuarek frequented Sokoto to a greater extent than they do to-day, and played an important part in the politics of those days. Sometimes we find them fighting on the side of the Fulani and at others lending aid to the Gobirawa. We cannot accept unreservedly as evidence of increasing aridity the fact that during recent years the Tuarek have been pressing further south, for they are only returning to pastures where they were formerly accustomed to graze their flocks and herds. The inference is that the restraint of European military occupation served temporarily to limit seasonal migrations to and fro across the frontier, but increasing desiccation in the north has developed so great a congestion of the population that the migrations are assuming their former proportions to an ever increasing degree.

However doubtful may be the nature and cause of tribal movements in the past, there is incontestible evidence that in Sokoto failure of water supply and decreasing yields of crops are causing a very definite, though gradual, movement southward of the agricultural community of the province. It is only quite recently that this movement has been recognised. Its extent and its ultimate results, supposing the process of desiccation continues, are matters which cannot yet be fully appreciated. That this movement is apt to escape notice is ascribed by Mr. Arnett to two causes. "First, because the population is in layers. Where Habe farmers have been driven out by drought and diminishing yields, the Fulani or Adarawa, with their live stock and lighter methods of agriculture, are glad to take their place. . Again, when the grazing becomes too poor for the cattle, the Buzai and Tuarek, with their sheep and camels, are pleased to come in. The second cause of this movement escaping notice is that it is so 
THE ENCROACHMENT OF THE SAHARA ON THE SUDAN 185

gradual and never for any great distance at a time. The community does not rise in flight like locusts and arrive on masse in a new area. It is rather the continued hopping from field to field, from district to district, devouring all as it goes. ... The rearguard of the swarm has fortunately not yet reached this province. They are the sedentary Tuarek and Buzai on our northern borders. Beyond them are the nomad Tuarek of the desert."

\section{E. Williay Bovill.}

\section{(To be continued.)}

\footnotetext{
1 Henri Schirmer. Lo Sahera, pp. 120-138. Paris, 1893. E. F. Gautier. Sahara Algetrian, pp. 60-133. Paris, 1908.

Bull. Soc. Glol. 1876 . П., p. 135 .

- E. F. Gautier. Sahara Alglvion. Paris, 1908.

- Hanns Vischer. Acroes the Sahara from Tripoli to Bormw. London, 1910.

- Dr. H. Barth. Trasals and Discownies in North and Central Africa. Vol. I. London, 1857 .

- Henri Schirmer. Le Sahara, p. 303. Paris, 1893.

- Capt. Touchard. Treoaux at Raconnaissances de Pdndtration Saharionne. Paris, 1907.

- Colonel Tilho. Grographical Jowmal. Vol. 56, 1920, p. 169.

- Capt. Tilho. " " " 43, 1914, p. 442.

¿ Bull. Com. Travawx" Historiques, Tome" 29, 1914, p. I0. Capt. A. H. W. Haywood. Through Timbuctu and Across the Great Sahara, p. 277. London, 1912.

1 E. F. Geatier. Sahara Alghrion. Paris, 1908.

11 Henri Schirmer. Le Sakark, p. 307. Paris, 1893.

1" Capt. A. H. W. Haywood. Through Timbrach and Across the Great Sthara, p. 317. London, I912.

14 Henry Hubert. A mrales de Gdographie, XXVI., 1917, p. 377 at seg.

18 Anxales de Glographie, XXVI., 1917, P. 231. Emile Roubeud. Bullatin de Matidres Grasses, July, 1920.

- E. F. Gentier. Sahara Algdrien. Parin, 1908. H. S. W. Edwardes. Geographical Journal, Vol. 53, 1919, p. 206.

21 Bull. Com. Travaux Historiques, Tome 29, 1914, p. 132.

18 Ibid. p. I 5.

10 R. Chudeau. Sakara Soudandis, p. 244. Paris, rgog.

- Anmales de Glographie, Misy I5th, $19 \mathrm{II}$.

"1 H. S. W. Edwardes. Geographical Joumal, Vol. 53, 1919, p. 206.

" Commander Clapperton. Jourmal of a Second Expodition, p. 219. London, 1829 .
} 